\title{
First report of Acidovorax avenae subsp. avenae causing bacterial leaf blight of tea in Taiwan
}

\author{
I-Hsin Sung ${ }^{1} \cdot$ Yi-Ru Lai ${ }^{1} \cdot$ Chien-Jui Huang $^{1}$ (D) \\ Received: 20 March 2020 / Accepted: 28 March 2020 / Published online: 20 April 2020 \\ (C) Società Italiana di Patologia Vegetale (S.I.Pa.V.) 2020
}

Keywords Camellia sinensis $\cdot$ Acidovorax avenae $\cdot$ Blight $\cdot$ Sequence typing

Severe leaf blight was observed on tea (Camellia sinensis L. cv. Sijichun) with the disease incidence of $60 \%$ in commercial orchards in Mingiian, central Taiwan from 2019 to 2020. The infected plants showed brown expanding lesions on the petiole bases of the young leaves and became completely blighted while the disease progressed. A bacterium was consistently isolated on nutrient agar from disinfected symptomatic tissue. Two representative isolates, CsNT01 and CsNT02, were identified by comparison of $16 \mathrm{~S}$ rDNA sequence and multilocus sequence typing with concatenated sequences of $g m c, u g p B$, pilT, lepA, trpB, and gltA genes (Feng et al. 2009). The sequences were deposited at GenBank under accession Nos. MT192602-MT192603, and MT199266-MT199277. The 16S rDNA sequences of the isolates shared $99.92 \%$ identity to that of $A$. avenae subsp. avenae type strain ATCC 19860 (EU024134) by BlastN analysis. Phylogenetic analysis of the six concatenated genes revealed the tea isolates well clustered with $A$. avenae subsp. avenae strains. The tea isolates presented phenotypic characters similar to Acidovorax avenae as determined with API $20 \mathrm{NE}$ system (Biomerieux). For fulfillment of Koch's postulates, tea cv. Sijichun seedlings were inoculated by immersing leaves in a bacterial suspension $\left(1 \times 10^{7} \mathrm{CFU} \mathrm{mL}^{-1}\right.$ in $0.05 \%$ Silwet L-77) for $30 \mathrm{~s}$. The inoculated plants were incubated at $28{ }^{\circ} \mathrm{C}$ for 3 days in closed plastic bags and subsequently for 4 days on a greenhouse bench. The artificially inoculated tea leaves showed brown lesions indistinguishable from those caused by natural infection. The control leaves remained symptomless. The causal

Electronic supplementary material The online version of this article (https://doi.org/10.1007/s42161-020-00547-w) contains supplementary material, which is available to authorized users.

Chien-Jui Huang

chienjui.huang@mail.ncyu.edu.tw

1 Department of Plant Medicine, National Chiayi University, No. 300, Syuefu Rd, Chiayi City 60004, Taiwan, Republic of China bacterium was repeatedly isolated from the blighted leaves and confirmed by PCR with the primers Aaaf5, Aaaf3/Aaar2 (Song et al. 2004). Recently, bacterial blight of tea caused by the same pathogen has been reported in China (Geng et al. 2017). To our knowledge, this is the first report of A. avenae subsp. avenae causing bacterial leaf blight of tea in Taiwan.

Acknowledgements This work was financed by the Ministry of Science and Technology (MOST, grant number 108-2313-B-415-006-MY2), Taiwan, R.O.C.

\section{Compliance with ethical standards}

Conflict of interest The authors declare that they have no conflict of interest.

Research involving human participants and/or animals The authors declare that no human participants and animals were involved in this study.

Informed consent This manuscript is new and not being considered elsewhere. All authors have approved the submission of this manuscript.

\section{References}

Feng J, Schuenzel EL, Li J, Schaad NW (2009) Multilocus sequence typing reveals two evolutionary lineages of Acidovorax avenae subsp. citrulli. Phytopathology 99(8):913-920

Geng GM, Zhao YQ, Zhu CC, Wang MX, Tian YL, Hu BS (2017) First report of bacterial leaf blight of tea (Camellia sinensis) caused by Acidovorax avenae in China. Plant Dis 101(10):1819

Song WY, Kim HM, Hwang CY, Schaad NW (2004) Detection of Acidovorax avenae ssp. avenae in rice seeds using BIO-PCR. J Phytopathol 152(11-12):667-676

Publisher's note Springer Nature remains neutral with regard to jurisdictional claims in published maps and institutional affiliations. 